\title{
Review of the Potential of Nuclear Hydrogen for Addressing Energy Security and Climate Change
}

The INL is a

U.S. Department of Energy

National Laboratory

operated by

Battelle Energy Alliance

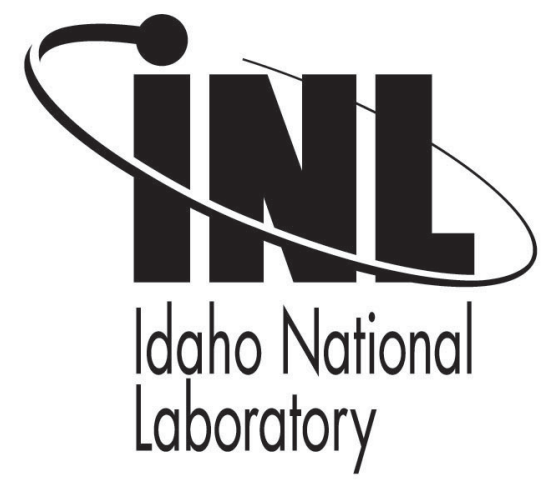

\section{Second International Meeting of the Safety and Technology of Nuclear Hydrogen Production, Control and Management}

\section{James E. O’Brien}

June 2010

This is a preprint of a paper intended for publication in a journal or proceedings. Since changes may be made before publication, this preprint should not be cited or reproduced without permission of the author. This document was prepared as an account of work sponsored by an agency of the United States Government. Neither the United States Government nor any agency thereof, or any of their employees, makes any warranty, expressed or implied, or assumes any legal liability or responsibility for any third party's use, or the results of such use, of any information, apparatus, product or process disclosed in this report, or represents that its use by such third party would not infringe privately owned rights. The views expressed in this paper are not necessarily those of the United States Government or the sponsoring agency. 


\title{
REVIEW OF THE POTENTIAL OF NUCLEAR HYDROGEN FOR ADDRESSING ENERGY SECURITY AND CLIMATE CHANGE
}

\author{
James E. O’Brien \\ Idaho National Laboratory \\ 2525 N. Fremont Ave., MS 3885, Idaho Falls, ID 83415 \\ james.obrien@inl.gov
}

\begin{abstract}
Nuclear energy has the potential to exert a major positive impact on energy security and climate change by coupling it to the transportation sector, primarily through hydrogen production. In the short term, this coupling will provide carbon-free hydrogen for upgrading increasingly lower quality petroleum resources such as oil sands, offsetting carbon emissions associated with steam methane reforming. In the intermediate term, nuclear hydrogen will be needed for large-scale production of infrastructure-compatible synthetic liquid fuels. In the long term, there is great potential for the use of hydrogen as a direct vehicle fuel, most likely in the form of light-duty pluggable hybrid hydrogen fuel cell vehicles. This paper presents a review of the potential benefits of large-scale nuclear hydrogen production for energy security (i.e. displacing imported petroleum) and reduction of greenhouse gas emissions. Lifecycle benefits of nuclear energy in this context are presented, with reference to recent major publications on this topic. The status of US and international nuclear hydrogen research programs are discussed. Industry progress toward consumer-grade hydrogen fuel cell vehicles are also be examined.
\end{abstract}

\section{INTRODUCTION}

Despite recent shifts in priorities by the US Department of Energy, there continues to be a strong level of interest in the development of large-scale non-fossil hydrogen production technologies. In terms of the transportation sector, this interest is driven by the nearterm demand for hydrogen for refining of increasingly low-quality petroleum resources, the expected intermediate-term demand for carbon-neutral synthetic fuels, and the potential long-term demand for hydrogen as an environmentally benign direct transportation fuel [1-3]. Additional important non-transportation markets for large-scale hydrogen production include ammonia production and (potentially) carbon-free steel production [4].
At present, hydrogen production in North America is based almost exclusively on steam reforming of methane. From a long-term perspective, methane reforming may not be sustainable for large-scale hydrogen production since natural gas is a non-renewable resource that exhibits large volatility in price and since methane reforming and other fossil-fuel conversion processes emit large quantities of greenhouse gases to the environment [5]. Non-fossil carbon-free options for hydrogen production include conventional water electrolysis coupled to either renewable (e.g., wind) energy sources or nuclear energy. The renewable-hydrogen option may be viable as a supplementary source, but would be very expensive as a large-scale stand-alone option [6, 7]. Conventional electrolysis coupled to nuclear base-load power can approach economical viability when combined with offpeak power, but the capital cost is high [8]. To achieve higher overall hydrogen production efficiencies, hightemperature thermochemical [9] or electrolytic [10] processes can be used. The required high temperature process heat can be based on concentrated solar energy [11] or on nuclear energy from advanced hightemperature reactors [12].

High-temperature nuclear reactors have the potential for substantially increasing the efficiency of hydrogen production from water, with no consumption of fossil fuels, no production of greenhouse gases, and no other forms of air pollution. Advanced nuclear hydrogen production can be accomplished via high-temperature electrolysis (HTE) or thermochemical processes, using high-temperature nuclear process heat [13]. In order to achieve their best efficiencies, these processes require high-temperature operation $\left(\sim 850^{\circ} \mathrm{C}\right)$ and are therefore tied to the development of advanced high-temperature nuclear reactors. A conceptual depiction of a hightemperature gas-cooled reactor coupled to a hightemperature electrolysis system is shown in Fig. 1. In this scheme, the primary helium coolant serves as the working fluid to drive a gas-turbine power cycle, which provides the electrical energy required for the high-temperature electrolysis process. In addition, some of the hot helium 


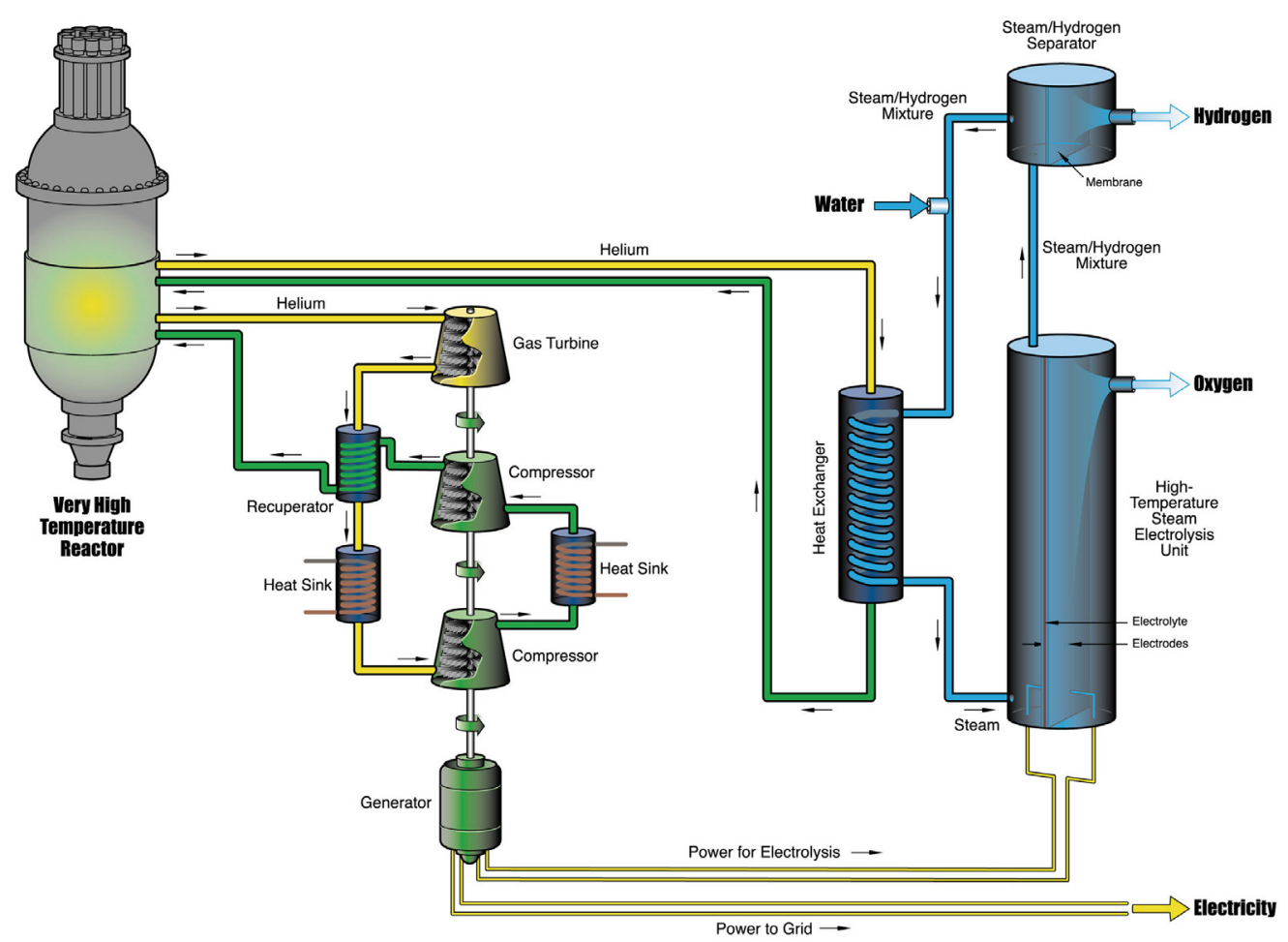

Figure 1. Concept for high-temperature electrolysis system coupled to an advanced nuclear reactor.

is used to deliver high-temperature nuclear process heat directly to the endothermic HTE process. Hightemperature electrolytic water-splitting supported by nuclear process heat and electricity has the potential to produce hydrogen with overall thermal-to-hydrogen efficiencies of $50 \%$ or higher, based on high heating value. This efficiency is similar to that of the thermochemical processes [14, 15], but without the severe corrosive conditions of the thermochemical processes and without the fossil fuel consumption and greenhouse gas emissions associated with hydrocarbon processes.

From 2003 - 2009, development and demonstration of advanced nuclear hydrogen technologies were supported by the US Department of Energy under the Nuclear Hydrogen Initiative [16]. During 2009, this program sponsored a technology down-selection activity in which an independent review team recommended HTE as the most appropriate advanced nuclear hydrogen production technology for near-term deployment [17].

The INL HTE program also includes an investigation of the feasibility of direct syngas production by simultaneous electrolytic reduction of steam and carbon dioxide (coelectrolysis) at high temperature using solidoxide cells. Syngas, a mixture of hydrogen and carbon monoxide, can be used for the production of synthetic liquid fuels via Fischer-Tropsch or other synthesis processes. This concept, coupled with nuclear energy, provides a possible path to reduced greenhouse gas emissions and increased energy independence, without the major infrastructure shift that would be required for a purely hydrogen-based transportation system [18-21].
Furthermore, if the carbon dioxide feedstock is obtained from biomass, the entire concept would be climateneutral.

As an alternative to centralized large-scale systems with direct coupling to high-temperature reactors, distributed hydrogen production could be accomplished using modular HTE units powered from grid electricity and an alternate high-temperature heat source such as concentrated solar energy [22] or a biomass gasifier [23]. This approach could be quite economical if off-peak electricity is used [24].

This paper will provide an overview of the potential for nuclear hydrogen to contribute to energy security in the transportation sector, while reducing emissions of greenhouse gases and relieving concerns about climate change.

\section{PERFORMANCE PREDICTIONS FOR DEDICATED NUCLEAR HYDROGEN PLANTS}

To demonstrate the performance potential of advanced nuclear hydrogen systems, detailed process analyses have been performed [15]. Summary results are presented in Fig. 2. This figure shows overall hydrogen production efficiencies, based on high heating value, plotted as a function of reactor outlet temperature. The figure includes a curve that represents $65 \%$ of the thermodynamic maximum efficiency [25], assuming $T_{L}=20^{\circ} \mathrm{C}$. Three different advanced-reactor/powerconversion combinations were considered: a heliumcooled reactor coupled to a direct recuperative Brayton 


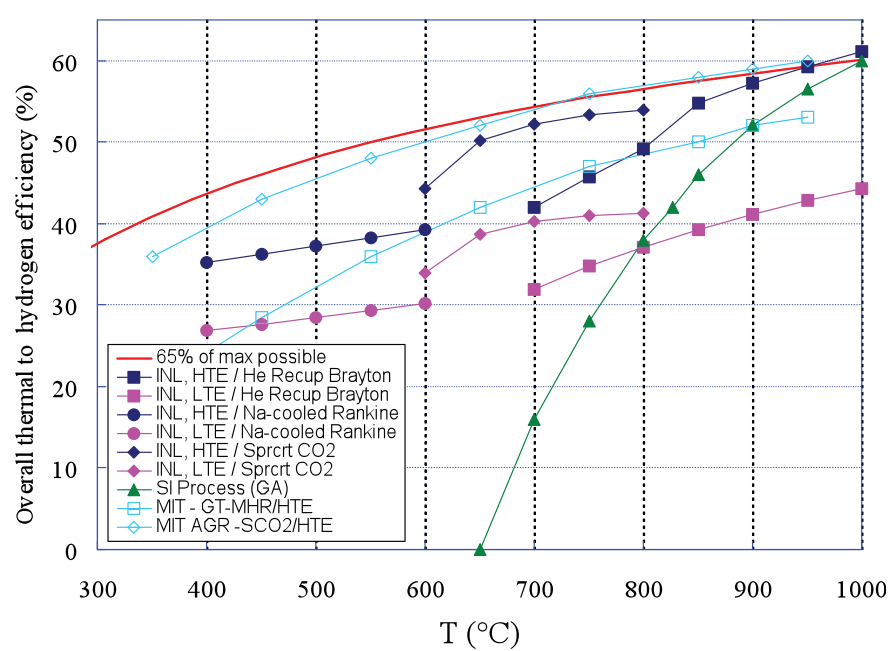

Figure 2. Overall thermal-to-hydrogen production efficiencies based on HHV for several reactor/process concepts, as a function of reactor outlet temperature.

cycle, a supercritical $\mathrm{CO}_{2}$-cooled reactor coupled to a direct recompression cycle, and a sodium-cooled fast reactor coupled to a Rankine cycle. The system analyses were performed using UniSim [26] software. Each reactor/power-conversion combination was analyzed over a reactor outlet temperature range appropriate for the power conversion system under consideration. The figure shows results for both HTE and low-temperature electrolysis (LTE). Results of system analyses performed at MIT [14] are also shown. The lower MIT curve, labeled MIT-GT-MHR/HTE represents overall efficiency predictions for a helium-cooled reactor with a direct Brayton cycle power conversion unit. The upper MIT curve, labeled MIT-AGR-SCO2/HTE represents overall efficiency predictions for a $\mathrm{CO}_{2}$-cooled advanced gas reactor with a supercritical $\mathrm{CO}_{2}$ power conversion unit.

For reactor outlet temperatures of $600-800^{\circ} \mathrm{C}$, the supercritical $\mathrm{CO}_{2} /$ recompression power cycle is superior to the He-cooled/Brayton cycle concept. This conclusion is consistent with results presented in reference [14]. Finally, an efficiency curve for the SI thermochemical process [27] is also shown. The results presented in Fig. 4 indicate that, even when detailed process models are considered, with realistic component efficiencies, heat exchanger performance, and operating conditions, overall hydrogen production efficiencies in excess of $50 \%$ can be achieved for HTE with reactor outlet temperatures above $850^{\circ} \mathrm{C}$. The efficiency curve for the SI process also includes values above $50 \%$ for reactor outlet temperatures above $900^{\circ} \mathrm{C}$, but it drops off quickly with decreasing temperature, and falls below values for LTE coupled to high-temperature reactors for outlet temperatures below $800^{\circ} \mathrm{C}$. Note that even LTE benefits from higher reactor outlet temperatures because of the improved power conversion thermal efficiencies associated with higher reactor outlet temperatures. Current planning for the Next Generation Nuclear Plant (NGNP) [12] indicates that reactor outlet temperatures will be at or below $800^{\circ} \mathrm{C}$, which favors HTE.

\section{LIFE CYCLE BENEFITS OF NUCLEAR ENERGY}

Several comprehensive life cycle analyses (LCA) have been completed in recent years to quantify the external costs associated with all forms of energy production and utilization. External costs are often not considered in traditional economic analysis. Nevertheless, these costs are accrued by society in terms of environmental damage and health impacts over the lifetime of the energy system. The ExternE (external costs of energy) project, sponsored by the European Commission, produced a series of papers aimed at assessing external costs related to power production and transportation. A summary of the methodology and key results of this work is presented in reference [28]. An example result from this study is presented in Fig. 3. This figure indicates that nuclear power has the lowest external costs in comparison to coal, oil, and natural gas-based power. The largest contributors for the fossil fuels are $\mathrm{SO}_{2}$ and $\mathrm{NO}_{\mathrm{x}}$. The costs shown for nuclear represent an upper bound related to long-term cancers.

Another recent LCA study at Stanford [29] provided a review and ranking of energy-related solutions to global warming, air pollution, mortality and energy security. Other impacts such as water supply, land use, wildlife, resource availability, thermal pollution, water pollution, nuclear proliferation and undernutrition were also quantified. In terms of transportation options, a summary of results from [29] is presented in Fig. 4. This figure provides estimates of future annual US premature deaths from vehicles replacing light- and heavy-duty gasoline onroad vehicles. Lowest impacts from this study were associated with battery-electric vehicles (BEV), powered

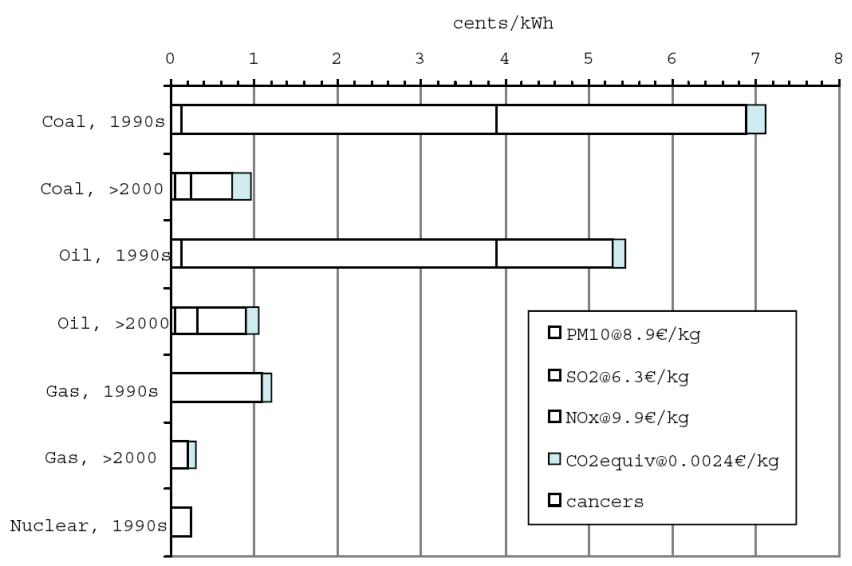

Figure 3. External costs for electric power production (from Friedrich et al. [28]) 


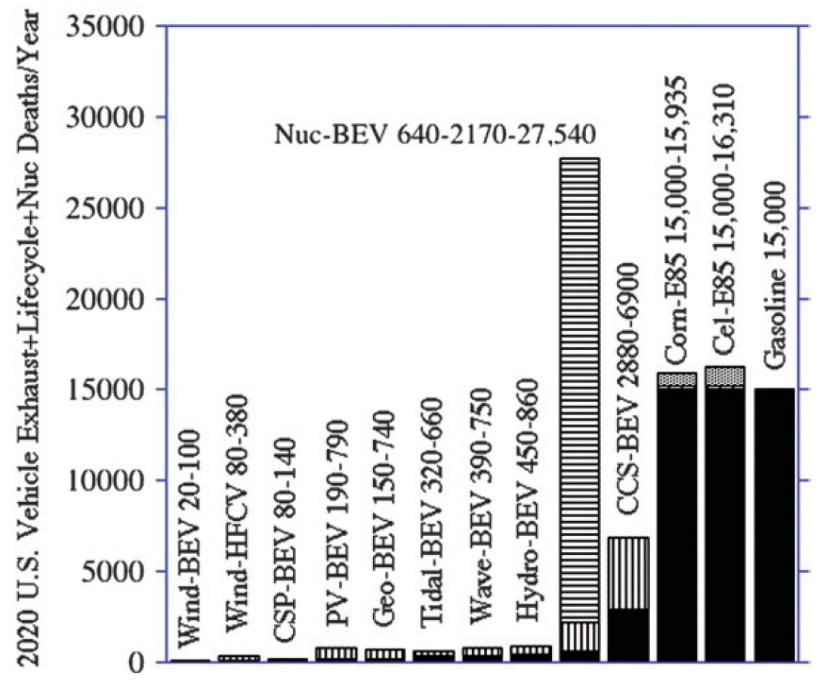

Figure 4. Estimates of future (ca. 2020) premature deaths due to onroad vehicle air pollution associated with various potential gasoline/diesel substitutes (from Jacobsen [29]).

by wind-based electricity. In general, the highest scoring options according to this study were battery-electric and fuel-cell vehicles powered by renewable electricity (wind, solar, hydro, etc.). The nuclear-BEV option scored poorly, as a result of a large penalty added to the premature deaths estimate associated with an assumed elevated risk of nuclear war associated with the development of nuclear energy. Nuclear was the only option for which an elevated risk of war-related deaths was assumed. When that additional presumed risk is removed, the nuclear-BEV option appears very favorable.

With regard to hydrogen production, an LCA analysis published by Utgikar et al. [30] examined the environmental impact of large-scale hydrogen production by high-temperature electrolysis coupled to an advanced reactor. Results were presented in terms of the global warming potential and acidification potential associated with atmospheric emissions from hydrogen production plants based on HTE, steam methane reforming (SMR), wind power with conventional electrolysis, solar thermal, solar photovoltaic, hydro and biomass. The results of this study indicated that the HTE process has lower greenhouse gas emission and acidification potential than all other processes, with the exception of wind- and hydro-powered conventional electrolysis. SMR emits nearly six times the greenhouse gas emissions and has three times greater acidification potential compared to the HTE process.

\section{DEPLOYMENT OPTIONS AND POTENTIAL IMPACT}

A continuum of possible deployment magnitudes and implementation strategies can be considered for nuclear hydrogen production. One possible early deployment strategy is to tie the hydrogen production process to the grid and make use of inexpensive off-peak electricity.
This strategy would not require a large capital investment since only the electrolyzers would be required. Hydrogen could be produced via HTE using grid electricity (HTE requires $\sim 32 \mathrm{~kW} \cdot \mathrm{hr} / \mathrm{kg}_{\mathrm{H} 2}$ ) and natural gas-based process heat for less than $\$ 2.0 / \mathrm{kg}$, assuming an electricity cost of $\$ 5.00 / \mathrm{MW} \cdot \mathrm{hr}$, a heat cost of $\$ 5.00 / \mathrm{MBTU}$, an SOEC capital cost of $\$ 200 / \mathrm{kW}$ (based on demonstrated SECA [31] cost target of $\$ 400 / \mathrm{kW}$ for SOFCs; the same hardware operated in the electrolysis mode consumes approximately twice the power as is generated in the fuel cell mode), and a stack life of 40,000 hr. This production cost is competitive today. Of course, this method of hydrogen production is not carbon-free, since grid electricity is used and the process heat is based on natural gas. Nevertheless, initial HTE deployments will undoubtedly be based on this type of concept, rather than a full-scale dedicated nuclear hydrogen plant.

Another example of a potential early deployment concept for HTE has been proposed by Forsberg [24]. He has performed a study of a concept in which hydrogen and oxygen are produced from grid electricity during offpeak times when electricity prices are low, stored underground, and subsequently fed into a combustor and advanced high-temperature steam turbine for efficient electrical generation during peak price time periods. The economics of this concept work out favorably for electrical grids that exhibit large differences in electricity prices between low-demand and high-demand time periods.

In the short term, demand for hydrogen is primarily tied to petroleum upgrading and ammonia production. Therefore, short-term strategies should be focused on meeting these demands in a cost-competitive fashion. In terms of penetrating the transportation market, supplemental non-fossil hydrogen can be used for refining and upgrading petroleum. Demand for hydrogen for this purpose is growing dramatically as increasingly lower quality petroleum resources such as oil sands and heavy crudes are exploited. Approximate hydrogen upgrading requirements are presented in Fig. 4 for a range of hydrocarbon feedstocks, ranging from light sweet crude to coal. Requirements for direct feed to a Fischer-Tropsch process and energy-equivalent pure hydrogen as a direct vehicle fuel are also shown. For example, the quantity of hydrogen required to produce a refined product from bitumen is about double that required for light sweet crude. Oil shale hydrogen requirements are still higher. Production of liquid fuels from biomass or coal is extremely hydrogen-intensive.

Considering bitumen, several large steam methane reforming (SMR) hydrogen production plants are located near Edmonton, Alberta to enable the conversion of oil sands into a synthetic crude oil that can then be further processed by traditional refineries. These large SMR plants have a typical hydrogen production capacity on the order of 100 million standard cubic feet per day (SCFD), 


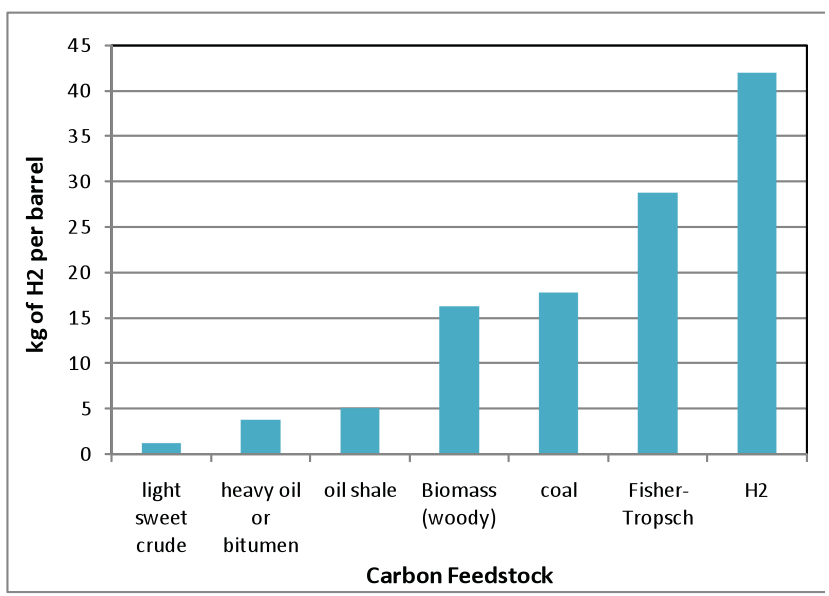

Figure 5. Hydrogen requirements for processing of carbon feedstocks to produce liquids fuels.

while consuming about 33 million SCFD of natural gas and emitting 49 million SCFD of $\mathrm{CO}_{2}$ into the atmosphere [32].

The total oil-sands natural gas consumption rate is currently around 1.4 billion SCFD, with the projected demand by 2015 at 2.1 billion SCFD [33]. New large potential sources of natural gas are being developed, such as Beaufort Sea gas, to be transported south via the proposed controversial Mackenzie Valley pipeline. Nevertheless, the growth in demand for natural gas to support oil sands development may exceed the capacity of the available natural gas, even with the Mackenzie Valley pipeline (projected to supply 1.9 billion SCFD) [34].

With traditional SMR, natural gas is consumed both as a feedstock to the reformer and to provide the hightemperature process heat required to overcome the endothermic heat requirement of the reformation reaction at $800-850^{\circ} \mathrm{C}$. The upgrading requirement for bitumen using natural gas-based hydrogen results in life-cycle greenhouse gas (GHG) emissions that are 16\% higher than the LCA emissions associated with light crude production and utilization. The increased LCA emissions for Venezuelan heavy crude are similar [34]. Implementation of an alternate GHG-free hydrogen production strategy, such as nuclear-powered HTE would relieve some of the demand for natural gas while reducing LCA GHG emissions.

The scale of these SMR plants provides a basis of comparison to proposed nuclear HTE plants. A 600 $\mathrm{MW}_{\text {th }}$ high-temperature reactor coupled to a dedicated HTE plant would have a hydrogen production capacity of about 85 million SCFD [36], very similar to a large SMR plant. The economics of the nuclear-HTE option will improve as the demand for natural gas increases and reserves are depleted. The expected implementation of carbon taxes will also have an impact.

Beyond providing hydrogen for upgrading petroleum resources, HTE can also be used to support the production

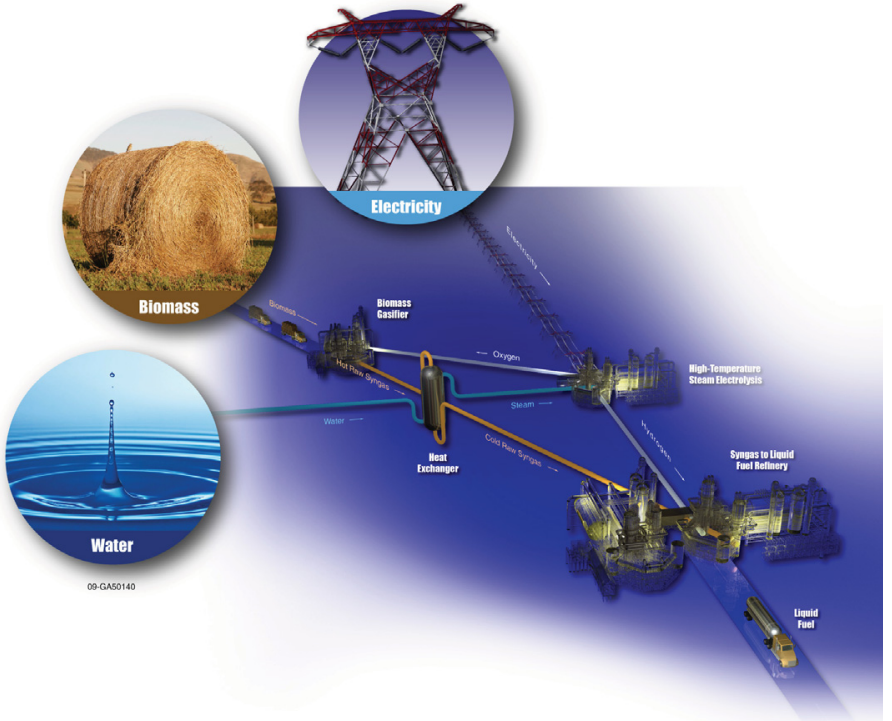

Figure 6. Concept for distributed biomass to liquids, using HTE for supplemental hydrogen.

of synthetic fuels from non-conventional carbon sources such as biomass [23] or coal [37], or directly from carbon dioxide via co-electrolysis [18]. The benefits of carbonfree supplemental hydrogen for biomass- and coal-toliquids are significant. For example, distributed production of synthetic liquid fuels based on biomass and supplemental hydrogen offers a method of producing carbon-neutral liquid fuels such as biodiesel and ethanol [23]. The concept for this hybrid energy system is provided in Fig. 6. In this concept, the high temperature process heat for HTE is provided by the biomass gasifier while the oxygen required for the gasifier is produced as a by-product of the HTE process. Supplemental hydrogen from electrolysis enables achievement of high carbon utilization such that about $95 \%$ of the carbon in the

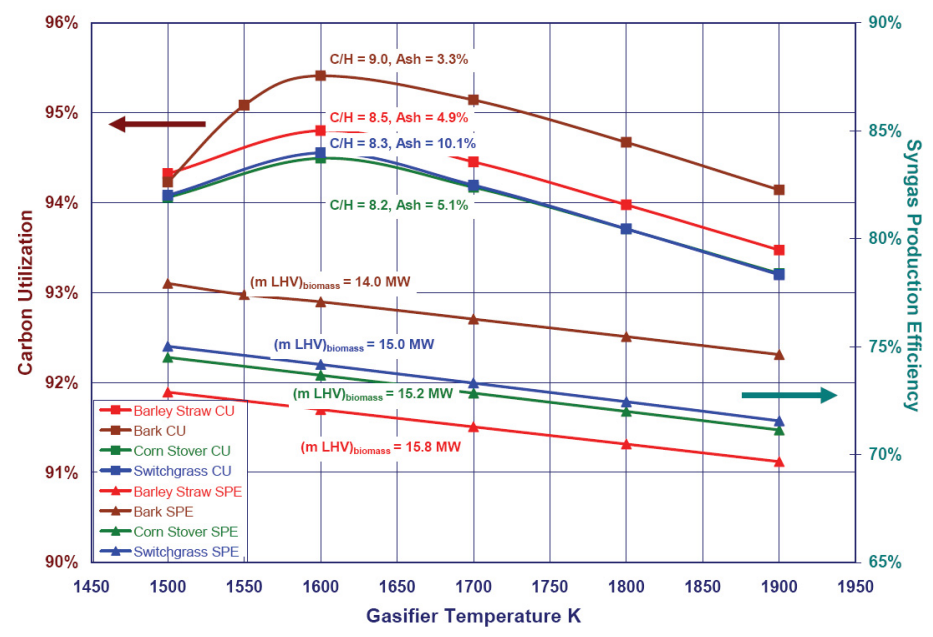

Figure 7. Carbon utilization and syngas production efficiency for various biomass feedstocks as a function of gasifier temperature (from [23]). 
biomass feedstock is retained in the syngas product, as shown in Fig. 7 [23]. Oxygen produced from the electrolysis process is used to control the oxidation rate in the oxygen-blown biomass gasifier. Syngas production efficiencies range from $70 \%$ to $73 \%$, depending on the gasifier temperature.

Traditional processes for producing syngas from biomass or coal also produce significant quantities of carbon dioxide that must be sequestered or directly released to the atmosphere. This issue is less significant when considering biomass, since the $\mathrm{CO}_{2}$ emitted can be considered as carbon-neutral. However, with traditional coal-to-liquids (CTL) technology, only about one-third of the carbon in the coal feedstock ends up in the liquid fuel product [38]. The remainder is immediately released to the atmosphere. Without carbon capture and sequestration, large-scale implementation of traditional CTL technology would result in a $118 \%$ increase in LCA greenhouse gas emissions, relative to the petroleum fuel that is displaced [39]. If supplemental hydrogen is available, nearly all of the carbon in the coal can end up in the liquid fuel product, resulting in only a very small percentage increase in LCA greenhouse gases, assuming the hydrogen is produced without carbon emissions. Therefore, supplemental hydrogen for this process should be obtained from an efficient non-carbon-emitting process such as high-temperature electrolysis (HTE) of steam powered by nuclear energy [10].

Coupling of the HTE process to CTL is particularly appealing because it is more efficient than conventional electrolysis and because it provides both hydrogen and oxygen at elevated temperature. The oxygen can be fed directly to a gasifier and the hydrogen can be used to reduce the excess carbon dioxide produced in the gasifier, via the reverse shift reaction. A system analysis of the nuclear/HTE-assisted CTL process was performed at INL [37]. A representative result from this study is shown in Fig. 8 which shows the dependence of syngas production efficiency and carbon utilization on coal moisture content. Carbon utilization increases with decreased moisture content, reaching a value of $98.8 \%$ for a moisture content of $16.1 \%$. The syngas production efficiency shown in Fig. 8 also appears to increase as the moisture content is reduced, but peaks at about $68.8 \%$ at a coal moisture content of $25 \%$. The slight drop in syngas production efficiency as the coal moisture content is reduced below $25 \%$ is the result of the need to increase the gasifier temperature to maintain a minimum heat exchanger approach temperature for the steam generator of approximately $20^{\circ} \mathrm{C}$. This drop in syngas production efficiency is consistent with results that show a drop in syngas production efficiency as the gasifier temperature increased. Note that the syngas production efficiencies for this process are considerably higher than those associated with the purely electrolytic co-electrolysis process.

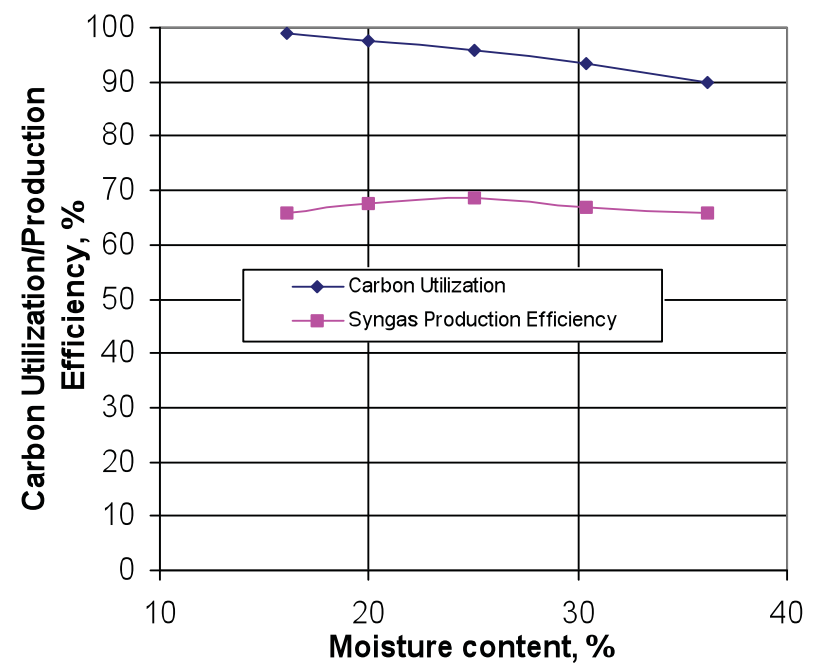

Figure 8. Carbon utilization and syngas production efficiency for CTL as a function of coal moisture content (from [37]).

Hydrogen can also be employed as a direct transportation fuel. Many books and articles have been written on the topic of "The Hydrogen Economy," some advocating strongly for the concept [40] and others concluding that the idea is ill-founded [41]. From an environmental perspective, the concept is certainly appealing, provided that the required hydrogen production is based on water splitting with clean carbon-free energy sources such as renewables or nuclear. In this case, hydrogen-powered transportation has the potential to relieve the growing demand for petroleum and natural gas, while simultaneously addressing concerns about emissions of greenhouse gases and other atmospheric pollutants. The concept also provides a mechanism that allows nuclear and renewable energy sources to contribute to the transportation sector, which is currently $95 \%$ powered by fossil fuels [42]. Of course, electric vehicles can also enable penetration of nuclear and renewable energy into the transportation sector via the grid.

Light-duty vehicles contributed 62 percent of all US transportation-related GHG emissions in 2003 and about $17 \%$ of all GHG emissions [43]. Transportation GHG emissions are also increasing at a faster rate than other sectors. These facts, together with concerns about energy security (really petroleum security) emphasize the importance of developing alternative non-fossil, noncarbon transportation fuels.

The supplemental power required to produce enough hydrogen to accomplish a specified impact can easily be estimated. For example, what additional electric power would be required to replace all light-duty vehicles in the US with hydrogen fuel-cell vehicles (FCVs)? The total number of light-duty vehicle miles traveled in the US in 2008 was estimated to be 2676 billion miles [44]. Several automobile manufacturers have active FCV development 
and demonstration programs. These demonstrations have provided early data on expected FCV hydrogen fuel economy. In August 2009, Toyota completed a DOE field evaluation of its Highlander (mid-size SUV) fuel cell hybrid vehicle, achieving an average fuel economy of 68.3 miles $/ \mathrm{kg}$ for a 331-mile trip in California. In November, 2009, Toyota, Honda, and Nissan participated in a 706-mile demonstration run of their prototype FCVs in Japan, achieving an average $73.6 \mathrm{miles} / \mathrm{kg}$. Based on these tests, an assumed average FCV fuel efficiency for future production vehicles of $60 \mathrm{miles} / \mathrm{kg}$ is reasonable. The electrical energy requirement for large-scale commercially available atmospheric low-temperature electrolysis is $45.6 \mathrm{~kW} \cdot \mathrm{hr} / \mathrm{kg}$ [45]. An additional 3.3 $\mathrm{kW} \cdot \mathrm{hr} / \mathrm{kg}$ is required for compression from atmospheric pressure to $30 \mathrm{MPa}$ (typical compressed hydrogen onboard-vehicle storage pressure), for a total of 48.9 $\mathrm{kW} \cdot \mathrm{hr} / \mathrm{kg}$. Based on these numbers, the total electrical power required to supply enough hydrogen to provide all the light-duty vehicle miles driven in the US in 2008 is $249 \mathrm{GW}$. This result is similar to a result given by Walters [46] based on a similar analysis. For comparison, the total electrical energy consumed in the US in 2007 was $4.16 \times 10^{9} \mathrm{MW} \cdot \mathrm{hr}$ [47], which corresponds to an average consumption rate of $474 \mathrm{GW}$. The total installed "nameplate" electric generating capacity in the US in 2007 was $1088 \mathrm{GW}$. Based on this difference between installed capacity and average utilization, there is significant potential to power hydrogen production from the grid right now, without adding any additional generating capacity. If the required power were to be provided by new plants, about $2501100 \mathrm{MW}$ plants (construction plans for two new $1100 \mathrm{MW}$ plants have recently been announced) would be needed, assuming a capacity factor of $90 \%$.

The preceding analysis was based on conventional electrolysis. The electrical energy requirement for HTE is $30-35 \mathrm{~kW} \cdot \mathrm{hr} / \mathrm{kg}$, depending on cell performance and operating conditions. Using $32 \mathrm{~kW} \cdot \mathrm{hr} / \mathrm{kg}$, and the same $3.3 \mathrm{~kW} \cdot \mathrm{hr} / \mathrm{kg}$ (although this could be reduced for a pressurized HTE process) for compression work, the total electrical requirement for $\mathrm{HTE}$ is $35.3 \mathrm{~kW} \cdot \mathrm{hr} / \mathrm{kg}$, which is $34 \%$ lower than for conventional electrolysis. The corresponding total electrical generating capacity required to supply enough hydrogen to provide all the light-duty vehicle miles driven in the US in 2008 would be $180 \mathrm{GW}$. HTE also requires high-temperature process heat. With a dedicated nuclear-HTE plant, such as the one shown conceptually in Fig. 1, this process heat would be supplied directly to the HTE unit via an intermediate heat exchanger. Current concepts for this application envision a $600 \mathrm{MW}_{\text {th }}$ high-temperature helium-cooled reactor with an outlet temperature of approximately $800^{\circ} \mathrm{C}$. Assuming a power cycle thermal efficiency of $50 \%$ (reasonable for high-temperature reactors), just over 660 of these hightemperature nuclear reactors would be required to supply the needed $180 \mathrm{GW}$, again assuming a 90\% capacity factor.

The supplemental (new plant construction) power requirements could be reduced by including consideration of pluggable hybrid electric vehicles (PHEVs), with the extended vehicle range beyond that provided by the batteries powered by hydrogen fuel cells (PHEV/FCVs). Approximately $30 \%$ of all vehicle miles are accrued by vehicles that travel less than 40 miles per day. Furthermore, if all vehicles had a 40-mile PHEV range, as much as $63 \%$ of all vehicle miles could be provided by battery power [48-50]. Under this scenario, the supplemental capacity for hydrogen production would be reduced to $92 \mathrm{GW}$ with LTE and $67 \mathrm{GW}$ with HTE. The supplemental power requirement for recharging the batteries for all these PHEVs must also be included. Specifications for the Chevy Volt, to be available for purchase in 2011, indicate that the pure-electric range of the vehicle will be 40 miles, with a full-recharge energy requirement of only $8 \mathrm{~kW} \cdot \mathrm{hr}$. If we assume a fleetaverage recharge requirement of $12 \mathrm{~kW} \cdot \mathrm{hr}$ per 40 miles, the supplemental power required to recharge all these vehicles is about $58 \mathrm{GW}$. Therefore, the total supplemental power requirement would be reduced to 150 GW for PHEV/FCVs for LTE-based hydrogen and 124 GW for HTE-based hydrogen, with a corresponding reduction in the required number of new nuclear plants. Supplemental power requirements for these various options are summarized in Fig. 9. So, with LTE-based hydrogen, about 150 new plants would be needed. Compared to the 104 nuclear plants now in service in the US, this is not an outrageous number. If this electrical power were to be generated using wind power, 409,000 large 1.5 MW windmills (assumed capacity factor of 0.25 ) would be needed. These windmills would be distributed over a land area of about 45,000 square miles (70 acre footprint per windmill). It should be reemphasized that the requirements for new plant

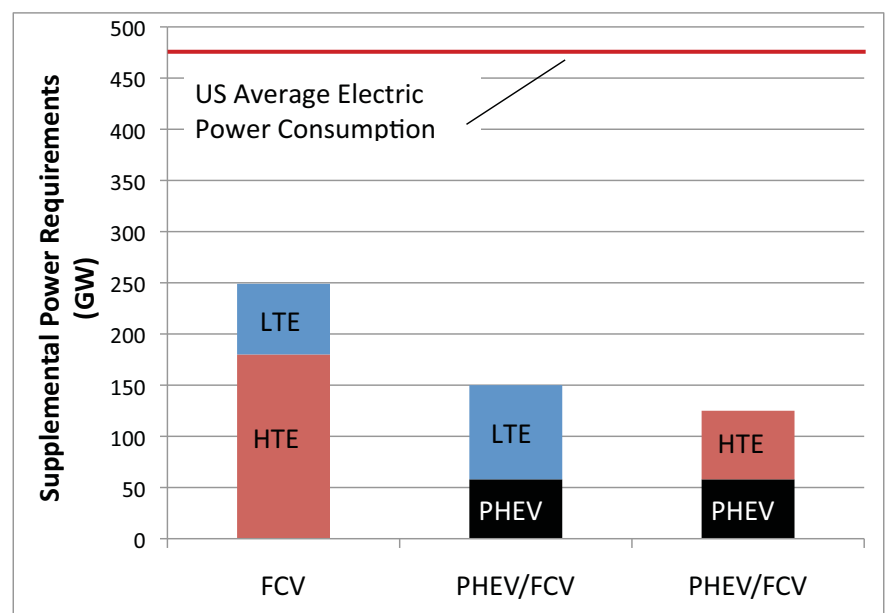

Figure 9. Supplemental power requirements for light-duty vehicles based on FCVs or PHEV/FCVs. 
construction could be reduced significantly by making use of current available excess off-peak grid capacity as much as possible.

\section{ECONOMICS}

A preliminary economic analysis has been performed to estimate the hydrogen production cost for a large-scale dedicated HTE plant coupled to an advanced hightemperature gas-cooled reactor [51]. The reference HTE plant considered for this particular analysis was driven by a $600 \mathrm{MW}_{\mathrm{t}}$ high-temperature helium-cooled reactor coupled to a direct Brayton power cycle with a reactor outlet temperature of $900^{\circ} \mathrm{C}$. Plant operating conditions used in the reference plant optimization were based on parametric studies performed using UniSim [26] process analysis software. The economic analysis was performed using the standardized H2A Analysis Methodology developed by the Department of Energy (DOE) Hydrogen Program [52], using realistic financial and cost estimating assumptions. Based on this methodology, and the various assumptions discussed in detail in reference [51], the estimated price of the hydrogen leaving the plant gate at 5 $\mathrm{MPa}$ pressure would be $\$ 3.23 / \mathrm{kg}$. This estimated price was shown to be most sensitive to the assumed after-tax internal rate of return (nominal assumed value was 10\%) and the cost of unplanned replacement costs. This estimated lifecycle HTE hydrogen production cost represents the cost of hydrogen leaving the plant gate, and does not include any additional storage, delivery, fuel taxes or other costs that the consumer might pay at the pump. Compared to the current hydrogen commodity price of about $\$ 2.50 / \mathrm{kg}$ (based on steam-methane reforming), this estimated cost is not unreasonable considering the volatility of the cost of the natural gas and the fact that the HTE technology does not emit greenhouse gases. Estimates of hydrogen production cost based on LTE depend strongly on electricity prices, but for large systems (1000 kg/day), with an assumed industrial electricity cost of $\$ 0.0483 / \mathrm{kWh}$, a hydrogen selling price of $\$ 4.15$ (FY2000 dollars) has been reported [53] based on the DOE H2A methodology. Note that any proposed new technology for large-scale hydrogen production must at a minimum be able to compete with this price.

\section{SUMMARY AND CONCLUSIONS}

With growing demand for hydrogen for petroleum refining, ammonia and synthetic fuels production and other applications, alternate sources of hydrogen are being developed. High temperature thermal water splitting processes in general and high temperature steam electrolysis in particular offer relatively efficient carbonfree options for large-scale hydrogen production. HTE makes use of solid oxide electrolysis cells to electrochemically split steam into hydrogen and oxygen at about $850^{\circ} \mathrm{C}$. Large-scale system analyses have provided a favorable assessment of the overall performance of large-scale hydrogen production schemes based on HTE, with overall thermal-to-hydrogen efficiencies approaching $50 \%$, based on the lower heating value of the produced hydrogen. Detailed life-cycle analyses of nuclear energy for hydrogen production and power generation for support of electric vehicles yield generally favorable conclusions with regard to minimizing greenhouse gas emissions and acidification potential. A broad range of implementation options are available for nuclear hydrogen for both the short and long term. The technology has significant potential to make a valuable contribution towards energy security and GHG reduction in the transportation sector.

\section{ACKNOWLEDGMENTS}

This work was supported by the U.S. Department of Energy, Office of Nuclear Energy, Nuclear Hydrogen Initiative and Next Generation Nuclear Plant Programs under DOE Operations Office Contract DE-AC0705 ID 14517.

\section{REFERENCES}

1. Forsberg, C. W., "The Hydrogen Economy is Coming. The Question is Where?" Chemical Eng. Progress, Dec. 2005, pp. 20-22.

2. Lewis, D., "Hydrogen and its relationship with nuclear energy," Progress in Nuclear Energy, Vol. 50, pp. 394-401, 2008.

3. Kruger, P., "Nuclear Production of Hydrogen as an Appropriate Technology," Nuclear Technology, Vol. 166, pp. 11-17, 2009.

4. Forsberg, C. W., "Future hydrogen markets for largescale hydrogen production systems," Int. J. Hydrogen Energy, Vol. 32, pp. 431-439, 2007.

5. Duffey, R. B., "Nuclear production of hydrogen: When worlds collide," International Journal of Energy Research," Vol. 33, pp. 126-134, 2009.

6. Granovskii, M., Dincer, I., and Rosen, M. A., "Greenhouse gas emissions reduction by use of wind and solar energies for hydrogen and electricity production: economic factors," Int. J. Hydrogen Energy, V. 32, 2007, pp. 927-931.

7. Rand, D. A. J., and Dell, R. M., Hydrogen Energy: Challenges and Prospects, Royal Society of Chemistry, 2008.

8. Floch, P-H., Gabriel, S., Mansilla, C., and Werkoff, F., "On the production of hydrogen via alkaline electrolysis during off-peak periods," Int. J. Hydrogen Energy, Vol. 32, 2007, pp. 4641-4647.

9. Schultz, K. R., Brown, L. C., Besenbruch, G. E. and Hamilton, C. J., "Large-Scale Production of 
Hydrogen by Nuclear Energy for the Hydrogen Economy," Report GA-A24265, Feb. 2003, 22p.

10. O'Brien, J. E., Stoots, C. M., Herring, J. S., and Hartvigsen, J. J., "Performance of Planar HighTemperature Electrolysis Stacks for Hydrogen Production from Nuclear Energy," Nuclear Technology, Vol. 158, pp. 118 - 131, May, 2007.

11. Steinfeld, A. "Solar thermochemical production of hydrogen," Solar Energy, V 78, No 5, pp. 603-615, May 2005.

12. Southworth, F., Macdonald, P. E., Harrell, D. J., Park, C. V., Shaber, E. L., Holbrook, M. R., and Petti, D. A., "The Next Generation Nuclear Plant (NGNP) Project," Proceedings, Global 2003, pp. 276-287, 2003.

13. Elder, R., and Allen, R., "Nuclear heat for hydrogen production: Coupling a very high/high temperature reactor to a hydrogen production plant," Progress in Nuclear Energy, Vol. 51, pp. 500-525, 2009.

14. Yildiz, B., and Kazimi, M. S., "Efficiency of Hydrogen Production Systems Using Alternative Nuclear Energy Technologies," Int. J. of Hydrogen Energy, Vol. 31, pp. 77-92, 2006.

15. O’Brien, J. E., McKellar, M. G., and Herring, J. S., "Performance Predictions for Commercial-Scale High-Temperature Electrolysis Plants Coupled to Three Advanced Reactor Types," 2008 International Congress on Advances in Nuclear Power Plants, June 8-12, 2008, Anaheim, CA.

16. Schultz, K., Sink, Pickard, P., Herring, J. S., O’Brien, J. E., Buckingham, R., Summers, W., and Michele Lewis, M., "Status of the US Nuclear Hydrogen Initiative," Proceedings of ICAPP 2007, Paper 7530, Nice, France, May 13-18, 2007; The Nuclear Renaissance at Work, V. 5, Societe Francaise d'Energie Nucleaire - ICAPP 2007, pp. 2932-2940.

17. Varrin, R. D., Reifsneider, K., Scott, D. S., Irving, P., and Rolfson, G., "NGNP Hydrogen Technology Down-Selection; Results of the Independent Review Team Evaluation," Dominion Engineering report\# R6917-00-01, August, 2009.

18. O’Brien, J. E., McKellar, M. G., Stoots, C. M., Herring, J. S., and Hawkes, G. L., "Parametric Study of Large-Scale Production of Syngas via High Temperature Electrolysis," International Journal of Hydrogen Energy, Vol. 34, pp. 4216-4226, May, 2009.

19. Stoots, C. M., O’Brien, J. E., "Results of Recent High-Temperature Co-electrolysis Studies at the Idaho National Laboratory," in press, International Journal of Hydrogen Energy, Vol. 34, Issue 9, pp. 4208-4215, May 2009.

20. Jensen, S. H., Larsen, P. H., Mogensen, M., "Hydrogen and synthetic fuel production from renewable energy sources," Int. J. Hydrogen Energy, Vol. 32, pp. 3253-3257, 2007.
21. Mogensen, M., Jensen, S. H., Hauch, A., Chorkendorff, lb., and Jacobsen, T., "Reversible Solid Oxide Cells," Ceramic Engineering and Science Proceedings, V 28, n 4, Advances in Solid Oxide Fuel Cells III - A Collection of Papers Presented at the 31st International Conference on Advanced Ceramics and Composites, 2008, p 91-101.

22. Arashi, H., Naito, H., and Miura, I., "Hydrogen Production from High-Temperature Steam Electrolysis using Solar Energy," Int. J. Hydrogen Energy, Vol. 16, No. 9, pp. 603-608, 1991.

23. Hawkes, G. L. and McKellar, M. G., "Liquid Fuel Production from Biomass via High Temperature Steam Electrolysis," 2009 AIChE Annual Meeting, November 8 - 13, 2009, Nashville, TN.

24. Forsberg, C. W., "Economics of Meeting Peak Electricity Demand using Hydrogen and Oxygen from Base-Load Nuclear or Off-Peak Electricity," Nuclear Technology, Vol. 166, pp. 18-26, 2009.

25. O’Brien, J. E., “Thermodynamic Considerations for Thermal Water Splitting Processes and HighTemperature Electrolysis," 2008 ASME International Congress and Exposition, paper\# IMECE200868880, Boston, Nov., 2008.

26. UniSim Design, R360 Build 12073, Copyright (C)2005-2006 Honeywell International Inc.

27. Brown, L. C., Lentsch, R. D., Besenbruch, G. E., Schultz, K. R., "Alternative Flowsheets for the Sulfur-Iodine Thermochemical Hydrogen Cycle," AIChE Journal, April 2003.

28. Friedrich, R., Rabl, A., and Spadaro, J. V., "Quantifying the Costs of Air Pollution: the ExternE Project of the EC," Pollution Atmospherique, pp. 77 - 104, Dec. 2001.

29. Jacobsen, M. Z., "Review of Solutions to Global Warming, Air Pollution, and Energy Security," Energy and Environmental Science, Vol. 2, pp. 148 173, 2009.

30. Utgikar, V., and Thiesen, T., "Life cycle assessment of high temperature electrolysis for hydrogen production via nuclear energy," International Journal of Hydrogen Energy, Vol. 31, pp. 939-944, 2006.

31. Surdoval, W. A., "U.S. Department of Energy's SECA Program: 2008 Progress and Plans," ECS Transactions, Vol. 17, No. 1, pp. 3-7, 2009.

32. Spath, P. L., and Mann, M. K., "Life Cycle Assessment of Hydrogen Production via Natural Gas Steam Reforming," NREL/TP-570-27637, 2001.

33. National Energy Board, "Canada's Oil Sands: Opportunities and Challenges to 2015: An Update," June, 2006.

34. Backer, T. Duff, B., et al., "Tar Sands and Shale Oil Addendum to: Peak Oil Production and the Implications to the State of Connecticut," Report to Legislative Leaders and the Governor, Dec. 2007. 
35. Bergerson, J., and Keith, D., "Life Cycle Assessment of Oil Sands Technologies," Alberta Energy Futures Project, Paper No. 11, November, 2006.

36. O’Brien, J. E., McKellar, M. G., Harvego, E. A., and Stoots, C. M., "High-Temperature Electrolysis for Large-Scale Hydrogen and Syngas Production from Nuclear Energy - System Simulation and Economics," International Conference on Hydrogen Production, ICH2P-09, Oshawa, Canada, May 3-6, 2009.

37. Harvego, E. A., Mckellar, M. G., and O’Brien, J. E., "System Analysis of Nuclear-Assisted Syngas Production from Coal," 4th Int. Topical Mtg. on High Temperature Reactor Technology, paper\# HTR200858085, Washington, DC, Sept. 2008.

38. Forsberg, C. W., "Is Hydrogen the Future of Nuclear Energy?" Proceedings, International Topical Meeting on the Safety and Technology of Nuclear Hydrogen Production, Control, and Management, ANS Embedded Topical, 2007.

39. US Environmental Protection Agency, "Greenhouse Gas Impacts of Expanded Renewable and Alternative Fuels Use," Fact Sheet EPA420-F-07-035, April 2007.

40. Scott, D. S., Smelling Land: The Hydrogen Defense Against Climate Catastrophe," Canadian Hydrogen Assoc., 2007.

41. Kreith, F., "Fallacies of a Hydrogen Economy: A Critical Analysis of Hydrogen Production and Utilization," Journal of Energy Resources Technology, Vol. 126, No. 4, pp. 249-256, Dec. 2004.

42. U. S. Department of Energy, Transportation Energy Data Book, Edition 28, 2009.

43. US Environmental Protection Agency, "Greenhouse Gas Emissions from the US Transportation Sector, 1990-2003," March 2006.

44. U. S. Energy Information Administration, Annual Energy Outlook 2009, Supplemental Tables, 2009.

45. Norsk Hydro Fact Sheet, Atmospheric Electrolyzers, 2008.

46. Walters, L., Wade, D., and Lewis, D., "Transition to a Nuclear/Hydrogen Energy System," The Nuclear Engineer, Vol. 43, No. 6, 2002.

47. U. S. Energy Information Administration, Electric Power Annual, 2008.

48. Santini, D. and Vyas, A., "More Complications in Estimation of Oil Savings via Electrification of Light-duty Vehicles," presented at PLUG-IN 2008 Conference in San Jose, CA, July 2008.

49. Vyas, A. and Santini, D., "Use of National Surveys for Estimating 'Full' PHEV Potential for Oil-Use Reduction," presented at PLUG-IN 2008 Conference in San Jose, CA, July 2008.

50. American Physical Society, "Energy Future: Think Efficiency, How America Can Look within to
Achieve Energy Security and Reduce Global Warming," September 2008.

51. Harvego, E. A., McKellar, M. G., Sohal, M. S., O'Brien, J. E., and Herring, J. S., "System Evaluation and Economic Analysis of a Nuclear Reactor Powered High Temperature Electrolysis Hydrogen Production Plant," Journal of Energy Resources Technology, in review, 2009.

52. U.S. DOE Hydrogen Program Website, DOE H2A Analysis, http://www.hydrogen.energy.gov/h2a analysis.html.

53. Ivy, J., "Summary of Electrolytic Hydrogen Production," NREL Report NREL/MP-560-36734, September, 2004. 